University of Wollongong

Research Online

Faculty of Engineering and Information

Faculty of Engineering and Information

Sciences - Papers: Part B

2018

Radiosensitisation enhancement effect of BrUdR and Ta205 NSPs in combination with 5-Fluorouracil antimetabolite in kilovoltage and megavoltage radiation

Marjorie McDonald

University of Wollongong,mm281@uowmail.edu.au

Sianne Oktaria

University of Wollongong, so819@uowmail.edu.au

Konstantin K. Konstantinov

University of Wollongong, konstan@uow.edu.au

Anatoly B. Rosenfeld

University of Wollongong, anatoly@uow.edu.au

Michael L. F Lerch

University of Wollongong, mlerch@uow.edu.au

See next page for additional authors

Follow this and additional works at: https://ro.uow.edu.au/eispapers1

Part of the Engineering Commons, and the Science and Technology Studies Commons

Research Online is the open access institutional repository for the University of Wollongong. For further information contact the UOW Library: research-pubs@uow.edu.au 


\title{
Radiosensitisation enhancement effect of BrUdR and Ta205 NSPs in combination with 5-Fluorouracil antimetabolite in kilovoltage and megavoltage radiation
}

\begin{abstract}
This article demonstrates in vitro a synergistic effect on $9 \mathrm{~L}$ gliosarcoma cells when exposed to bromodeoxyuridine (BrUdR) and a low concentration (100 times lower than the IC50) of 5-Fluorouracil (5-FU), in combination with $x$-ray irradiation. The synergy is brought about by several important factors including the $x$-ray beam energy, atomic number of the $\operatorname{BrUdR}(Z=35)$, effectiveness of 5-FU in reducing the available repair processes and distribution of the BrUdR in and around the $9 \mathrm{~L}$ cells $(32 \%$ of the total substitution of BrUdR for thymidine into nucleus DNA). Our results show that the synergistic effect, evident in an optimised $125 \mathrm{kVp}$ x-ray field, leads to a radiosensitisation enhancement ratio at the $10 \%$ survival level (SER $10 \%$ ) of 2.11 . We highlight the importance of the aforementioned factors by similarly performed experiments for higher $\mathrm{Z}(\mathrm{Z}=73)$ tantalum pentoxide nano-structured particles $\left(\mathrm{Ta}_{2} \mathrm{O}_{5} \mathrm{NSPs}_{\text {) }}\right.$ that are substituted for the BrUdR in larger concentration ( 10 times). In the $\mathrm{Ta}_{2} \mathrm{O}_{5}$ NSPs experiments, no synergistic effect is observed in the $\mathrm{kVp}$ irradiation with optimal energy spectrum even though the effective $Z$ and NSP concentration is much higher than for BrUdR. All experiments were repeated using a $\mathrm{MV} \mathrm{x}$-ray irradiation field and no synergistic effect is observed for either the $\mathrm{BrUdR}$ or $\mathrm{Ta}_{2} \mathrm{O}_{5} \mathrm{case}$. We therefore hypothesise that the synergistic outcome is due to more drastic and complex damages induced by BrUdR under the exposure of $k V p$ radiation. Such damages are achieved by the localisation of the BrUdR in the DNA and the high LET (very short range) secondary electrons in combination with the 5-FU. In order to achieve similar synergistic effects in the more clinically relevant $x$-ray energy field the concentration of the high $\mathrm{Z}$ material needs to be greater in order to create a higher LET electron environment.
\end{abstract}

\section{Keywords}

enhancement, effect, combination, brudr, nsps, ta2o5, radiosensitisation, radiation, megavoltage, kilovoltage, antimetabolite, 5-fluorouracil

\section{Disciplines}

Engineering | Science and Technology Studies

\section{Publication Details}

McDonald, M., Oktaria, S., Konstantinov, K., Rosenfeld, A., Lerch, M., Corde, S. \& Tehei, M. (2018). Radiosensitisation enhancement effect of BrUdR and Ta205 NSPs in combination with 5-Fluorouracil antimetabolite in kilovoltage and megavoltage radiation. Biomedical Physics and Engineering Express, 4 (3), 034001-1-034001-14.

\section{Authors}

Marjorie McDonald, Sianne Oktaria, Konstantin K. Konstantinov, Anatoly B. Rosenfeld, Michael L. F Lerch, Stephanie Corde, and Moeava Tehei 


\title{
Radiosensitisation enhancement effect of $\mathrm{BrUdR}$ and $\mathrm{Ta}_{2} \mathrm{O}_{5} \mathrm{NSPs}$ in combination with 5-Fluorouracil antimetabolite in kilovoltage and megavoltage radiation
}

To cite this article before publication: Marjorie McDonald et al 2018 Biomed. Phys. Eng. Express in press https://doi.org/10.1088/20571976/aabab2

\section{Manuscript version: Accepted Manuscript \\ Accepted Manuscript is "the version of the article accepted for publication including all changes made as a result of the peer review process, and which may also include the addition to the article by IOP Publishing of a header, an article ID, a cover sheet and/or an 'Accepted Manuscript' watermark, but excluding any other editing, typesetting or other changes made by IOP Publishing and/or its licensors"}

This Accepted Manuscript is @ 2018 IOP Publishing Ltd

During the embargo period (the 12 month period from the publication of the Version of Record of this article), the Accepted Manuscript is fully protected by copyright and cannot be reused or reposted elsewhere.

As the Version of Record of this article is going to be / has been published on a subscription basis, this Accepted Manuscript is available for reuse under a CC BY-NC-ND 3.0 licence after the 12 month embargo period.

After the embargo period, everyone is permitted to use copy and redistribute this article for non-commercial purposes only, provided that they adhere to all the terms of the licence https://creativecommons.org/licences/by-nc-nd/3.0

\begin{abstract}
Although reasonable endeavours have been taken to obtain all necessary permissions from third parties to include their copyrighted content within this article, their full citation and copyright line may not be present in this Accepted Manuscript version. Before using any content from this article, please refer to the Version of Record on IOPscience once published for full citation and copyright details, as permissions will likely be required. All third party content is fully copyright protected, unless specifically stated otherwise in the figure caption in the Version of Record.
\end{abstract}

View the article online for updates and enhancements. 


\section{ABSTRACT}

This article demonstrates in vitro a synergistic effect on 9L gliosarcoma cells when exposed to bromodeoxyuridine (BrUdR) and a low concentration (100 times lower than the IC50) of 5-Fluorouracil (5$\mathrm{FU}$ ), in combination with X-ray irradiation. The synergy is brought about by several important factors including the $\mathrm{X}$-ray beam energy, atomic number of the $\mathrm{BrUdR}(\mathrm{Z}=35)$, effectiveness of 5-FU in reducing the available repair processes and distribution of the BrUdR in and around the $9 \mathrm{~L}$ cells $(32 \%$ of the total substitution of BrUdR for thymidine into nucleus DNA). Our results show that the synergistic effect, evident in an optimised $125 \mathrm{kVp} \mathrm{X}$-ray field, leads to a radiosensitisation enhancement ratio at the $10 \%$ survival level $\left(\mathrm{SER}_{10 \%}\right)$ of 2.11 . We highlight the importance of the aforementioned factors by similarly performed experiments for higher $\mathrm{Z}(\mathrm{Z}=73)$ tantalum pentoxide nano-structured particles $\left(\mathrm{Ta}_{2} \mathrm{O}_{5} \mathrm{NSPs}\right)$ that are substituted for the BrUdR in larger concentration ( 10 times). In the $\mathrm{Ta}_{2} \mathrm{O}_{5}$ NSPs experiments, no synergistic effect is observed in the $\mathrm{kVp}$ irradiation with optimal energy spectrum even though the effective $\mathrm{Z}$ and NSP concentration is much higher than for BrUdR. All experiments were repeated using a MV X-ray irradiation field and no synergistic effect is observed for either the $\mathrm{BrUdR}$ or $\mathrm{Ta}_{2} \mathrm{O}_{5}$ case. We therefore hypothesise that the synergistic outcome is due to more drastic and complex damages induced by BrUdR under the exposure of $\mathrm{kVp}$ radiation. Such damages are achieved by the localisation of the BrUdR in the DNA and the high LET (very short range) secondary electrons in combination with the 5-FU. In order to achieve similar synergistic effects in the more clinically relevant X-ray energy field the concentration of the high $\mathrm{Z}$ material needs to be greater in order to create a higher LET electron environment.

\section{INTRODUCTION}

Most of the recent technological advances in radiation oncology are linked with developing state-of-the-art techniques that allow for better geometrically targeting of lesions. These techniques include intensity modulated radiation therapy, image-guided radiation therapy, volumetric modulated arc therapy, stereotactic ablative body radiation therapy, and proton therapy (MacDonald et al 2007, Nutting et al 2011, Van de Water et al 2011). Their ultimate goal is to provide better dose conformity to the tumours while sparing the surrounding healthy tissue, ultimately allowing dose escalation, locally creating more DNA damages to the cancerous cells. A similar outcome can be achieved by introducing a high atomic number (Z) material into the lesions (Pignol et al 2003, Rahman et al 2009). This area is currently the subject of many investigations to enhance the impact of the ionising radiation dose on the target (Antosh et al 2015).

47

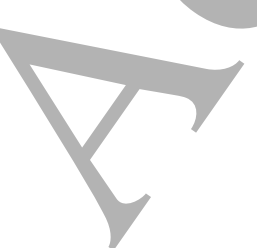


Making a tumour more sensitive to radiotherapy and maximise the absorbed dose in malignant cells is also a primary goal of chemotherapy. Chemotherapy is the utilisation of anti-cancer drugs to inhibit tumour growth (cytostatic agents) or destroy the cancerous cells (cytotoxic agents). The drug treatment can consist of only one or multiple drugs delivered at the same time. Moreover, this treatment can also be administered before, after, or concurrently with radiation therapy. 5-Fluorouracil (5-FU) is one chemotherapy drug that has been proven to be clinically effective. In particular, this drug has been found to specifically target the folate cycle so as to inhibit the DNA synthesis (Longley et al 2003).

To date, chemoradiotherapy with antimetabolites such as 5-FU has become a standard therapy for the treatment of a wide range of solid tumours, such as esophageal carcinoma, head and neck cancer, rectal cancer and gliosarcoma (Bedenne et al 2007, Adelstein et al 2003, Baglan et al 2002, Damodaran et al 2013). Chemoradiotherapy can therefore be considered a marriage between chemotherapy and radiotherapy, with the 5-FU drug being one of the most commonly used anticancer drugs utilised in this marriage, especially where the local regional control is often required (Harada et al 2006). An antimetabolite has the capability to inhibit the post-radiation damage repair (Lehnert 2014). In addition, agents that target the radioresistant S- phase of the cell cycle such as 5-FU, may be effective in preventing the instigation of the growth of the tumour cell (Lehnert 2014). 5-FU drug is integrated into nucleoside metabolism, causing the suppression of the RNA and the DNA replication (Ooyama et al 2007). Moreover the 5-FU drug is cell cycle dependent and it will most likely affect the radiation impact on rapidly proliferating tissues such as highgrade gliomas. Despite a plethora of research reporting the effectiveness of the 5-FU drug, in clinical treatment, the response rates are modest due to its high cytotoxicity and less therapeutic efficacy in the treatment of advance disease (Ilson 2008). The 5-FU drug, is therefore, often delivered in conjunction with other agents during radiation treatment to amplify its therapeutic impact on tumours.

Bromodeoxyuridine (BrUdR) is a halogenated pyrimidine that is known to sensitise cells to ionising radiation (Sano et al 1968, Dewey and Humphrey 1965). It is a classic radiosensitiser used in radiation treatment that display low Linear Energy Transfer (LET) such as x-rays and gamma-rays. Its role in radiosensitisation is not clear but its presence in the DNA strand seems to render the DNA to be more susceptible to radiation. This, in turn, leads to the observation of enhanced radiosensitivity of the carrier cells. The hypothesis among studies documented is that the incorporated BrUdR produce denser ionisation tracks that cause cluster DNA damage, together with the radicals formed by the low-LET ionising radiation (Epstein et al 1992). This clustered DNA damage leads to an increase in the relative biological effectiveness (RBE), making it as effective as high-LET radiation. There is also evidence suggesting that the radiosensitisation enhancing effect of BrUdR is through inhibiting the repair of damaged DNA and the fixation of radiation-induced damage (Iliakis et al 1989; Wang et al 1994).

Both Bromodeoxyuridine (BrUdR, $\left.\mathrm{Z}_{\mathrm{Br}}=35\right)$ and Iododeoxyuridine (IUdR, $\mathrm{Z}_{\mathrm{I}}=53$ ) compounds have been shown to sensitise cells to ionising radiation (Doiron et al 1999, Oktaria et al 2015, Corde et al 2004). Radio-sensitisers with high $\mathrm{Z}$ compositions, such as the aforementioned two agents, have been shown to cause more tissue damage by increasing the absorption or scattering of the radiation, as well as causing more local energy deposition via the overproduction of low energy secondary electrons (Brown et al 2014).

The simultaneous addition of the 5-FU drug and the BrUdR had been shown to significantly enhance the uptake of BrUdR into the cerebral tumour cell nuclei (Hoshino and Sano 1969). Moreover, they also found the combination of the 5-FU drug and the BrUdR has resulted in an increase in the irradiation sensitisation effects (Hoshino and Sano 1969). A possible explanation for their findings, according to Hoshino and Sano (1969) was that the presence of 5-FU in the DNA inhibits the biosynthetic mechanism, therefore forcing the cells in the mitotic stage to uptake thymidine analogue, BrUdR, in order to supply sufficient thymidine 
required to duplicate the DNA cells. This explanation is based on their assumption that the cells do not voluntarily incorporate BrUdR during their mitosis because they can synthesise the thymidine required for this DNA duplication. Due to this area of research being relatively unexplored, more studies are required to elucidate the relationship between the 5-FU drug and the BrUdR compound in radiation treatment, as well as the influence of the radiation energy.

Recently cancer immunotherapy has become an intensely active research field (Shao et al 2014, Emens et al 2017, Restifo et al 2016). Current strategies for immunomodulation have addressed the effectiveness of immunotherapy; however, there are still many fundamental challenges. These challenges include nonspecific modulation that may result in an unfavourable cytotoxic system while specific modulation methods may generate an insufficient therapeutic response on some target. Moreover, most immunotherapies, particularly those directed against solid cancers, have only benefited a small minority of patients (Velpurisiva et al 2017, Restifo et al 2016). Recent research using nanoparticles for cancer immunotherapy has demonstrated that immunotherapy generates significantly more sustained and robust anticancer effects when they are effectively bound in nanoparticles (Goldberg 2015). Nonetheless, the success of the integration of nanotechnology with cancer immunotherapy lies in finding the compatible nanoparticle candidate that has the capability to facilitate this therapy (Saleh and Shojaosadati 2016, Velpurisiva et al 2017).

Nanotechnology is a vastly expanding field with numerous and diverse applications due to the unique properties of the nanoparticles. The most distinguishable characteristic of the nanoparticles is that the properties that these particles possess are often of no resemblance to that of the equivalent bulk material (Buzea et al 2007). The significant reduction in size associated with the nanoparticles leads to a high particle number per unit mass as well as a much greater surface area (Buzea et al 2007). In radiation oncology, nanoparticles with high $\mathrm{Z}$ properties make them potentially ideal candidates as radio-sensitisers. An example of this is the use of gold nanoparticles in the radiobiological dose enhancement (Rahman et al 2009, Hainfeld et al 2008). The implementation of gold nanoparticles has already reached clinical trials (for example, see Libutti et al 2010). Although this dose enhancement effect is achieved with the gold nanoparticles, the optimal energy for dose enhancement is in the $\mathrm{kV}$ radiation. This poses a drawback as current clinical trials with gold nanoparticles are performed in the $\mathrm{MV}$ energy field. The use of tantalum pentoxidenanostructured particles $\left(\mathrm{Ta}_{2} \mathrm{O}_{5}\right.$ NSPs) is currently being studied as a radiation sensitiser based on its highmass energy absorption coefficient, and is novel in the field of nanomedicine. $\mathrm{Ta}_{2} \mathrm{O}_{5}$ NSPs have been experimentally shown to cause cell sensitisation in a higher energy MV radiation field (Brown et al 2017). This study found that when the $9 \mathrm{~L}$ cells containing $\mathrm{Ta}_{2} \mathrm{O}_{5}$ NSPs exposed to the radiation, a higher degree of damage (due to dose enhancement) is observed in comparison to the irradiated cells that were not treated by the $\mathrm{Ta}_{2} \mathrm{O}_{5}$ NSPs.

Given a mild to moderate therapeutic effectiveness in chemoradiotherapy with antimetabolites, investigation into improving the therapeutic effectiveness of radiation via radiation enhancers have been the focus of many researchers in this field. Research has long demonstrated that the delivered dose to the target was increased when a high $\mathrm{Z}$ material was in the targeted zone (Spiers 1949). Hence, a comprehensive breakthrough for local treatment and radiotherapy is dependent on the possibility of depositing significant energy within the tumour mass.

There is much evidence to suggest an effectiveness of both BrUdR and $\mathrm{Ta}_{2} \mathrm{O}_{5} \mathrm{NSPs}$ in the cancer treatment research (Hoshino T et al 1969, Brown et al 2014). However, to date, there has been no study published that compared the effectiveness between BrUdR and $\mathrm{Ta}_{2} \mathrm{O}_{5}$ NSPs in treating the cancerous cells, when simultaneously combined with 5-FU anti-cancer drug. The finding of this study can potentially provide a 
guide regarding the future direction of the cancer research. Moreover, it can also lead to a significant

Among the various models of brain tumour, the radioresistant 9L gliosarcoma model is most commonly used to replicate the glioblastoma multiforme (Ghods et al 2007). This model has been established as a valid experimental model for brain tumour therapy as it can best mimic the rapid growth and atrophy of intracerebral tumours (Ghods et al 2007). This subsequently allows for efficient testing of both chemotherapeutic and nanotechnology- based therapies.

This study primarily aims to investigate the radiation sensitisation effect of two different high Z elements when combined with the 5-FU drug at kilovoltage $(\mathrm{kVp})$ and megavoltage $(\mathrm{MV}) \mathrm{x}$-ray radiation energies. Any change in sensitisation measured between the two radiation energies is of particular interest especially in the context of the respective localisation of the elements within the whole target cell volume. The goal of this approach is to capitalise on their radiosensitisation properties in an attempt to achieve a synergistic effect on radioresistance 9L gliosarcoma cells when combine with 5-FU.

\section{METHODS AND MATERIALS}

\section{Cell Culture}

Gs-9L rat gliosarcoma cells originated from an N-nitrosomethylurea-induced tumour and were established by the European Collection of Cell Cultures. Cell cultures were maintain in Dulbecco's Modified Eagle medium (DMEM, Gibco BRL, AUS) containing 10\% (v/v) fetal bovine serum (FBS, Sigma-Aldrich, MO, USA) and $1 \%$ (v/v) penicillin/streptomycin (Pen Strep, Gibco BRL, AUS) in a T75 $\mathrm{cm}^{2}$ BD Falcon ${ }^{\mathrm{TM}}$ Tissue Culture Flasks (Franklin Lakes, NJ, USA) and incubated at $37^{\circ} \mathrm{C}$ in a humidified and $5 \%(\mathrm{v} / \mathrm{v}) \mathrm{CO}_{2}$ atmosphere.

\section{Exposure to pharmaceutical agents}

$1 \times 10^{5}$ cells were seeded in a T12.5 $\mathrm{cm}^{2}$ Flask and incubated for 48 hours to allow the cells to attach and divide. DMEM was replaced and the cells were then cultured in a $0.01 \mu \mathrm{M}$ 5-FU and/or $10 \mu \mathrm{M}$ BrUdR (Sigma-Aldrich, MO, USA) for 2 doubling times before radiation exposure. $\mathrm{Ta}_{2} \mathrm{O}_{5} \mathrm{NSPs}$ were synthesised by our laboratory using a thermal oxidation reaction. $\mathrm{Ta}_{2} \mathrm{O}_{5}$ nanoparticles were suspended in phosphate buffered saline (PBS) (without calcium and magnesium ions) and sonicated before being added to the cultured cells 24 hours prior to irradiation at a concentration of $113 \mu \mathrm{M}(50 \mu \mathrm{g} / \mathrm{ml})$.

\section{Flow cytometric Measurement of BrUdR incorporation in DNA}

After the cells are exposed to BrUdR for 2 doubling times, they were taken for the preparation prior to the measurement using a Becton Dickinson fluorescence-activated cell sorting (FACS) flow cytometer (BD LSR II; BD Biosciences, USA). The cells were stained with anti-BrUdR mouse monoclonal antibody (Clone MoBU-1) conjugated to Alexa Fluor 488 dye (highly specific for this nucleoside analogue) from Molecular Probe (Invitrogen, Carlsbad, CA, USA). Cell's DNA incorporating BrUdR was detected using this fluorescently labelled anti-BrUdR antibodies. This compound staining optimised for cellular labelling and detection. The stained nuclei were measured and analysed with flow cytometer with excitation at $488 \mathrm{~nm}$. The BrUdR labelling index (LI) is calculated. The BrUdR LI is the ratio of the number of BrUdR-positive cells to the total number of cells. 


\section{Flow cytometric Measurement of Internalisation of $\mathrm{Ta}_{2} \mathrm{O}_{5} \mathrm{NSPS}$}

After exposing of the cells to the NSPs for 24 hours, the cells were harvested, centrifuged at $1500 \mathrm{rpm}$ for 5 mins at $4{ }^{\circ} \mathrm{C}$ and washed twice with cold dulbecco's phosphate buffer solution with $\mathrm{Ca}^{2+} / \mathrm{Mg}^{2+}$ free (DPBS, Gibco BRL, AUS). Flow cytometric measurements were performed with the forward scatter (FSC) and side scatter (SSC). A minimum of $1 \times 10^{4}$ cells were analysed from the harvested cells sample.

\section{Confocal Microscope Imaging of Internalisation of $\mathrm{Ta}_{2} \mathrm{O}_{5} \mathrm{NSPS}$}

The cells were grown and cultured with NSPs in a ${ }^{\mathrm{TM}}{ }_{\mathrm{Lab}}-\mathrm{Tek}^{\mathrm{TM}}$ II Chamber Slide ${ }^{\mathrm{TM}}$ System 4 wells (growth area $=1.8 \mathrm{~cm}^{2}$ ) (Thermos-Scientific). After exposure to NSPs for 24 hours, light and fluorescence microscope images were obtained using a Leica confocal laser scanning microscope (Leica TCS SP5 Advanced System - UV-VIS-IR and X1-Port Access with SMD FCS and $\mathrm{CO}_{2}$ incubation chamber, Germany) with oil immersion objective lens and the accompany images manager software Leica Application Suite Advanced Fluorescence (LAS AF, v.2.6.1-7314, Germany).

\section{Irradiation procedure and set up}

Confluent monolayers cell cultures were irradiated in T12.5 $\mathrm{cm}^{2}$ flasks using a Nucletron Oldelft Therapax DXT 300 Series 3 Orthovoltage unit (Nucletron B.V., Veenendaal, The, Netherlands) and an Elekta Axesse linear accelerator with beam modulator (Elekta AB, Kungstensgatan, Stockholm, Sweden) at the radiation oncology department of Prince of Wales Hospital (Randwick, NSW, Australia). Selected doses (1, 2, 3, 5 and $8 \mathrm{~Gy}$ ) were delivered at the cell level in single fraction at room temperature and in full scatter conditions, with dose-rates of 0.7 and $5 \mathrm{~Gy} / \mathrm{min}$ for kilovoltage and megavoltage experiments respectively. This difference in dose rates has been shown by Oktaria (2017) to have insignificant effect on the survival of 9L cells. Moreover, the selected radiation energies have similar RBE on 9L surviving fraction.

For megavoltage (MV) irradiation, the energy selected was $10 \mathrm{MV}$ and cells monolayers were at $2.2 \mathrm{~cm}$ depth (depth of maximum dose), $102.2 \mathrm{~cm}$ from the source. For kilovoltage $(\mathrm{kV}) \mathrm{X}$-ray irradiation, cells monolayers were either facing the applicator, $50 \mathrm{~cm}$ from the source or at $5 \mathrm{~mm}$ depth, $52 \mathrm{~cm}$ from the source depending on flasks orientation. The additional filter was chosen to provide a photon energy spectrum whose effective energy approximates the maximum mass energy absorption for the high $\mathrm{Z}$ target relative to water (as shown in Figures 1a and 1b).

$$
\text { a }
$$

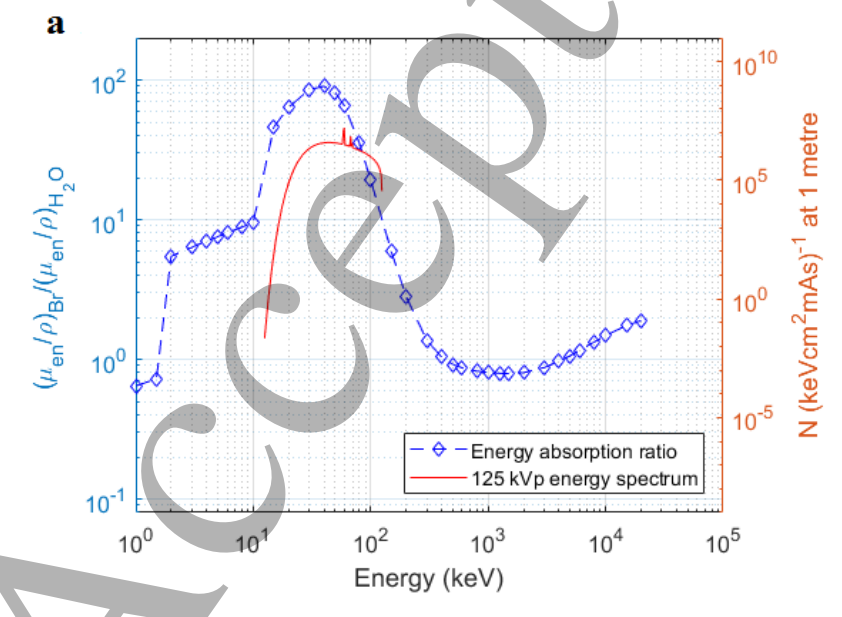

b

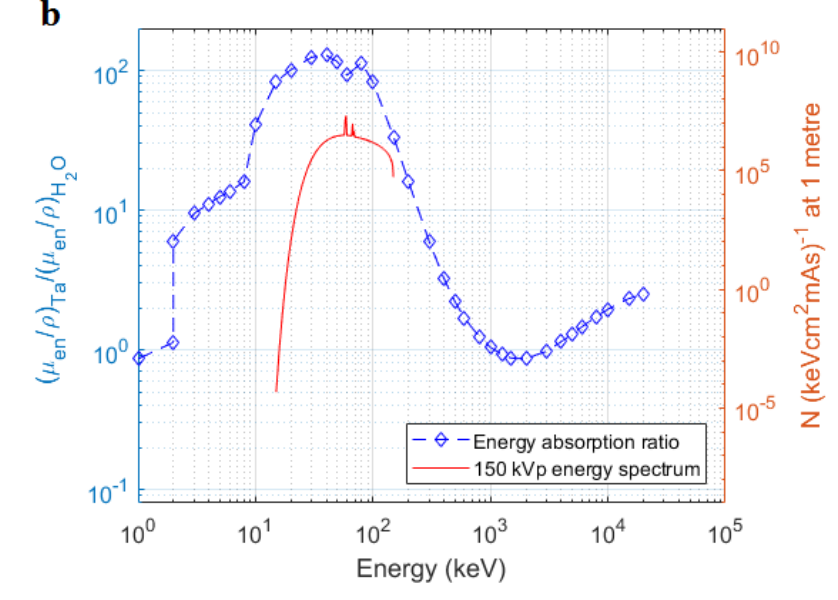


Figure 1. Ratio of the total mass energy absorption coefficient of (a) Bromine and (b) Tantalum to water as a function of energy (corresponding to the y-axis on the left). Output spectrum of an orthovoltage X-ray unit operating at (a) $125 \mathrm{kVp}$ and (b) $150 \mathrm{kVp}$ is also shown (corresponding to the y-axis on the right). The data for the output spectrum was generated using SpekCalc (Poludniowski et al 2009).

For BrUdR experiments, flasks were irradiated vertically the Pantak unit was operating at a peak voltage of $125 \mathrm{kVp}$ and $20 \mathrm{~mA}$ with additional filtration of $0.1 \mathrm{~mm} \mathrm{Cu}$ and $2.5 \mathrm{~mm} \mathrm{Al}(\mathrm{HVL}=6.70 \mathrm{~mm} \mathrm{Al})$. For $\mathrm{Ta}_{2} \mathrm{O}_{5}$ NSPs experiments, flasks were irradiated horizontally and the unit was chosen to operate at $150 \mathrm{kVp}$ and 20 $\mathrm{mA}$ with additional filtration of $0.35 \mathrm{~mm}$ of $\mathrm{Cu}$ and $1.5 \mathrm{~mm}$ of $\mathrm{Al}(\mathrm{HVL}=0.67 \mathrm{~mm} \mathrm{Cu})$. Beams were calibrated as per international protocols for absolute dosimetry and relative dosimetry data were applied to correct for changes compared to reference conditions. More details of the irradiation conditions can be found in (Oktaria et al 2015 and Brown et al 2017)

\section{In vitro assessment of radiation therapy effect and data analysis}

Cells were plated after irradiation at low densities in $100 \mathrm{~mm}$ diameter Petri dishes containing $10 \mathrm{ml}$ of complete DMEM. Depending on the prescribed dose, each irradiated sample inyolved a minimum of three cells densities with triplicate dishes for each density. After 15 doubling times, the colonies were fixed and stained with a mixture solution of $25 \%$ crystal violet and $75 \%$ ethanol. The cell clonogenic surviving fraction (SF) was then calculated and plotted vs. dose (D) and fitted with the linear quadratic model (LQ):

$$
S F=e^{\left(-\alpha D-\beta D^{2}\right)}
$$

The two fit parameters $\alpha\left(\mathrm{Gy}^{-1}\right)$ and $\beta\left(\mathrm{Gy}^{-2}\right)$ are determined by using the OriginLab graphing \& analysis software nonlinear curve-fitting algorithm. The sensitisation enhancement ratio at the $10 \%$ survival level $\left(\mathrm{SER}_{10 \%}\right)$ is determined by taking the ratio of doses to achieve $10 \%$ cell survival for cells without treatment (radiation alone) to those with treatment(s) (5-FU, BrUdR, $\mathrm{Ta}_{2} \mathrm{O}_{5}$ NSPs or combinations). The errors bars are standard errors of the means (SEM). The assays of all irradiation treatment conditions (with or without drugs/NSPs treated) were performed a minimum of three times independently.

\section{RESULTS}

\section{Detection of BrUdR incorporation in DNA}

The flow cytometer measures $32 \%$ of the total substitution of BrUdR for thymidine into nucleus DNA (see Figures 2.a and 2.b). However, the presence of 5-FU that served to inhibit thymidine synthesis did not increase the uptake of the BrUdR into cells DNA (see Figures 2.b and 2.c).

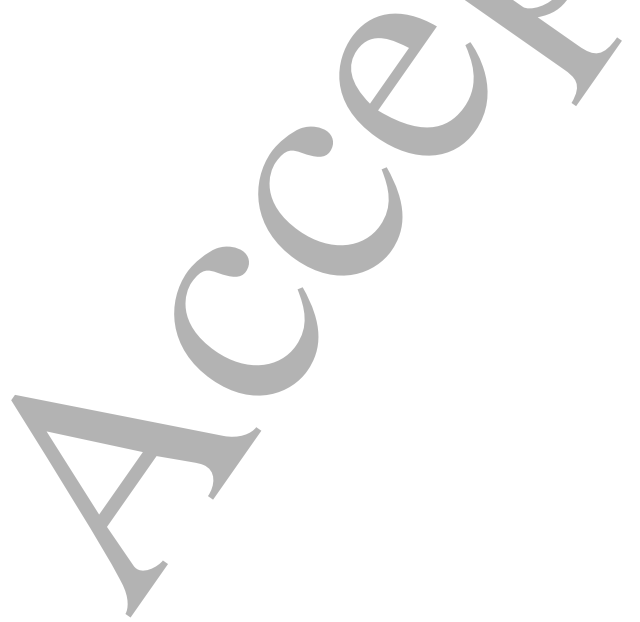


a

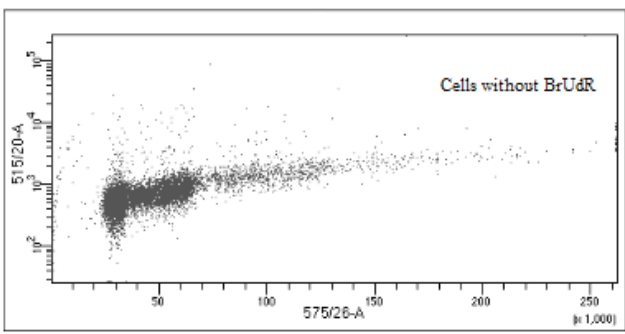

b

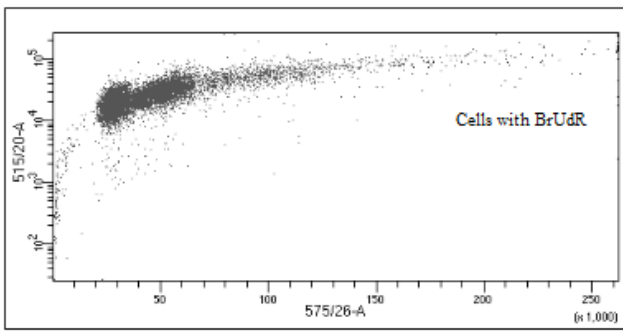

c

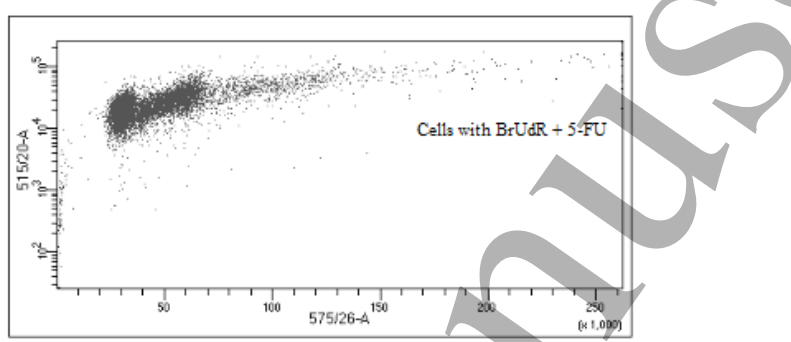

Figure 2. Flow cytometric measurements of the amount of Bromide from a $10 \mu \mathrm{M}$ concentration that is accessible to the DNA and is displayed in the graphs of the total DNA content (red fluorescence-575/26-A) versus amount of incorporated BrUdR (green fluorescence-515/20-A) (a) control sample (b) cells incubated with $10 \mu \mathrm{M}$ BrUdR (c) cells incubated with $10 \mu \mathrm{M}$ BrUdR and $0.01 \mu \mathrm{M}$ 5-FU for 2 doubling times before added fluorescently labelled anti-BrUdR antibodies prior to measurement.

\section{Internalisation of $\mathrm{Ta}_{2} \mathrm{O}_{5} \mathrm{NSPS}$}

a

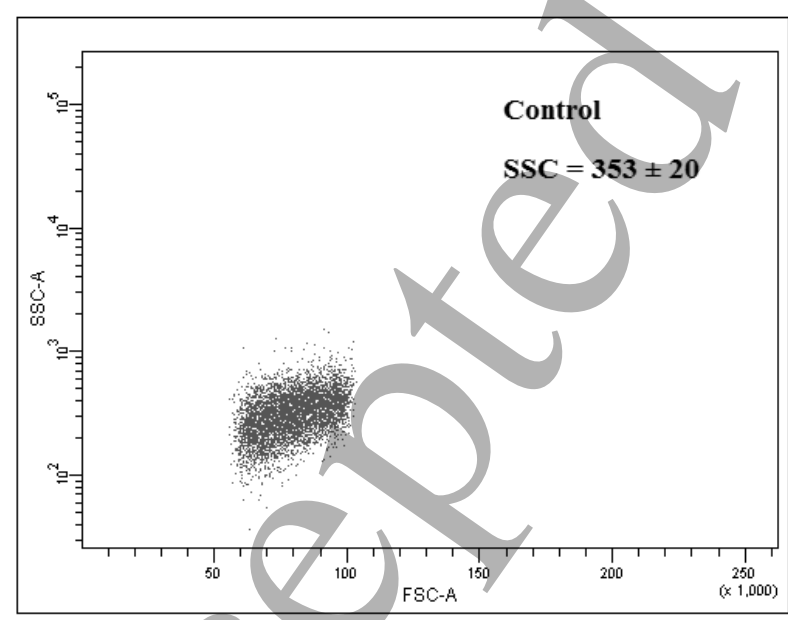

b

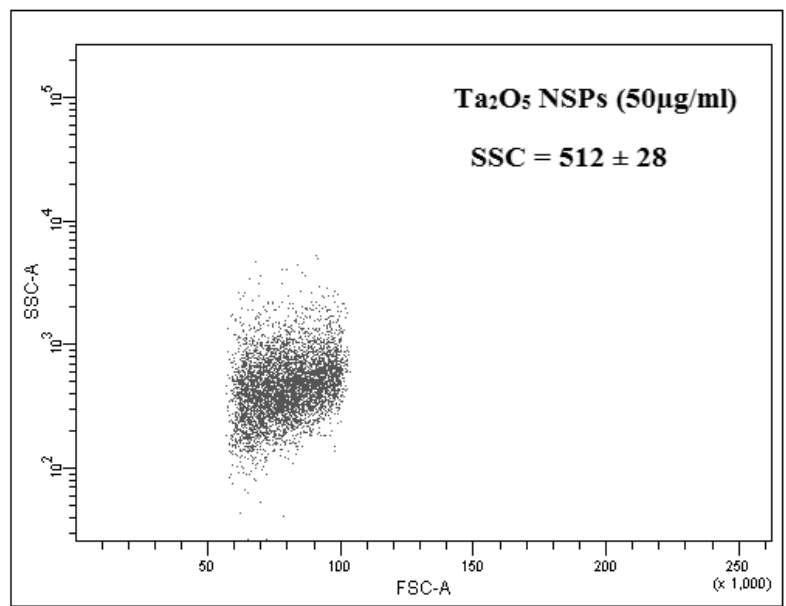

Figure 3. Flow cytometric measurements of the amount of internalisation of $\mathrm{Ta}_{2} \mathrm{O}_{5} \mathrm{NSPs}$ in cells (a) control sample set of cells that was incubated without NSPs (b) cells that incubated with NSPs 24 hours prior to measurement. 

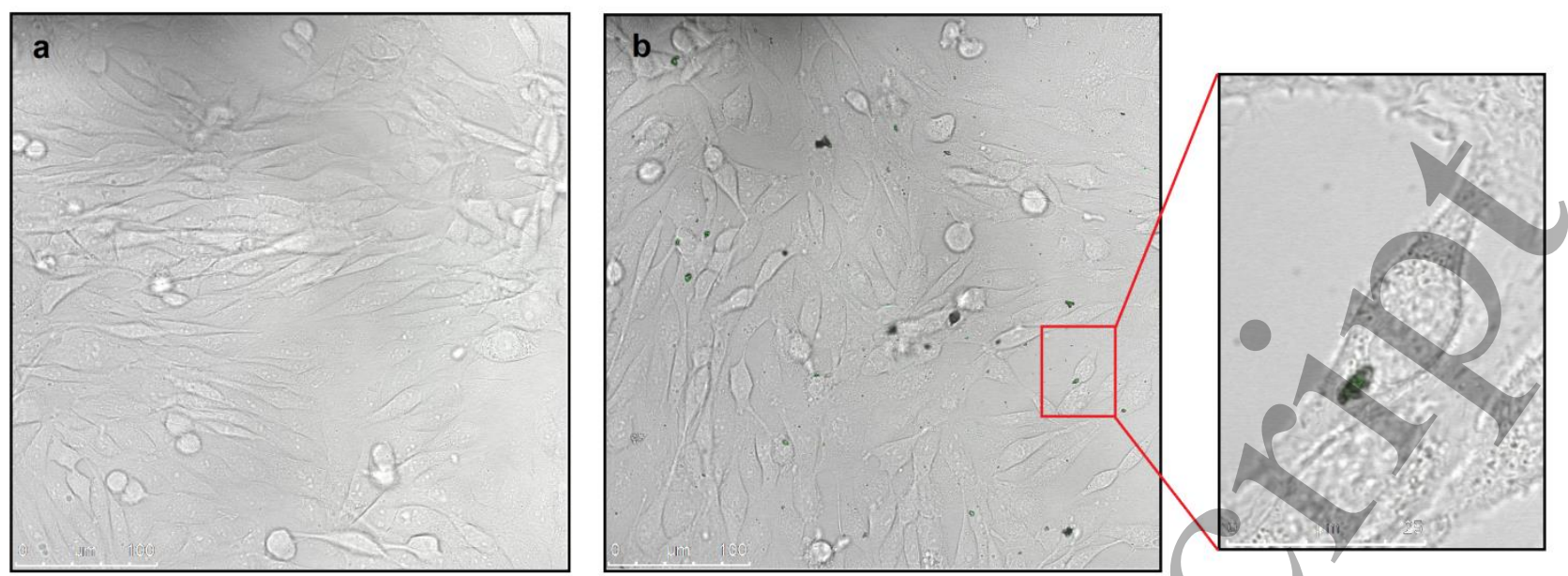

Figure 4. Confocal microscope images of (a) 9L cells that were incubated without NSPs (b) 9L cells that incubated with NSPs 24 hours prior to imaging.

The changed in mean side scattering (SSC) and mean forward scattering(FSC) represents the relative change in granularity and size of the cell, respectively. The gating is restricted between $60 \%-100 \%$, to eliminate dead cells and debris from analysis (Figure 3). From this the amount of internalisation of $\mathrm{Ta}_{2} \mathrm{O}_{5} \mathrm{NSPs}_{\mathrm{S}}$ on the cells is measured to increase the cellular granularity by $45 \%$. This measurement is used as a marker for internalisation of NSPs. Figure 4 (b) showed a relatively even distribution of $113 \mu \mathrm{M}$ of $\mathrm{Ta}_{2} \mathrm{O}_{5} \mathrm{NSPs}_{\text {. It }}$ shows that the NSPs are positioned in the culture in possible three manners; inside the cells, on the cells and in close proximity to the cells.

\section{Cytotoxicity of pharmaceutical agents on $9 \mathrm{~L}$ Cells}

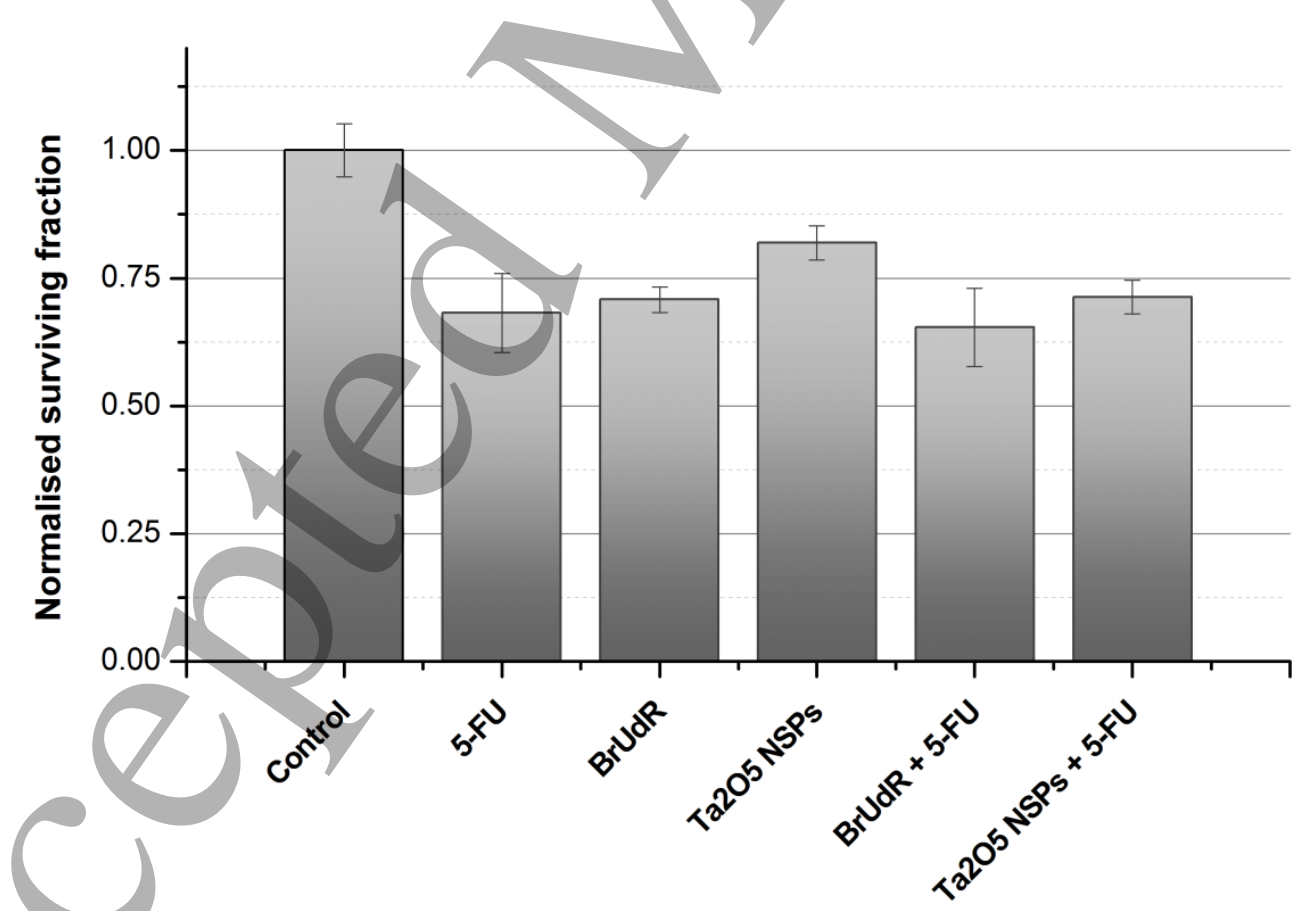

Figure 5. Normalised surviving fractions of $9 \mathrm{~L}$ cells with and without the individual components of the combination (i.e. 5-FU $+\mathrm{BrUdR}$ and 5-FU $+\mathrm{Ta}_{2} \mathrm{O}_{5} \mathrm{NSPs}$ ) of 3 independent experiments. Errors bars represent the SEM. 
The cytotoxicity of 5-FU on 9L cells is demonstrated by a surviving fraction of $68 \pm 7 \%$. The cytotoxicity of BrUdR on the cells resulted in a cell surviving fraction of $71 \pm 2 \%$. The $\mathrm{Ta}_{2} \mathrm{O}_{5}$ NSPs displayed modest toxicity on the cells. The cells surviving fraction after 24 hours exposure to $50 \mu \mathrm{g} / \mathrm{ml}$ of $\mathrm{Ta}_{2} \mathrm{O}_{5}$ NSPs was determined to be $82 \pm 3 \%$. When each of the aforementioned high- $\mathrm{Z}$ materials coexist with 5 -FU, it marginally increased the toxicity, although remained within the uncertainties (see Figure 5). The cytotoxicity of the individual combination of BrUdR and Ta2O5 NSPs with 5-FU resulted in the cells surviving fractions of $65 \pm 8 \%$ and $71 \pm 5 \%$, respectively.

\section{Comparison of 5-FU + BrUdR with 5-FU + $\mathrm{Ta}_{2} \mathrm{O}_{5} \mathrm{NSPS}$ with $\mathrm{kV} x$-ray}
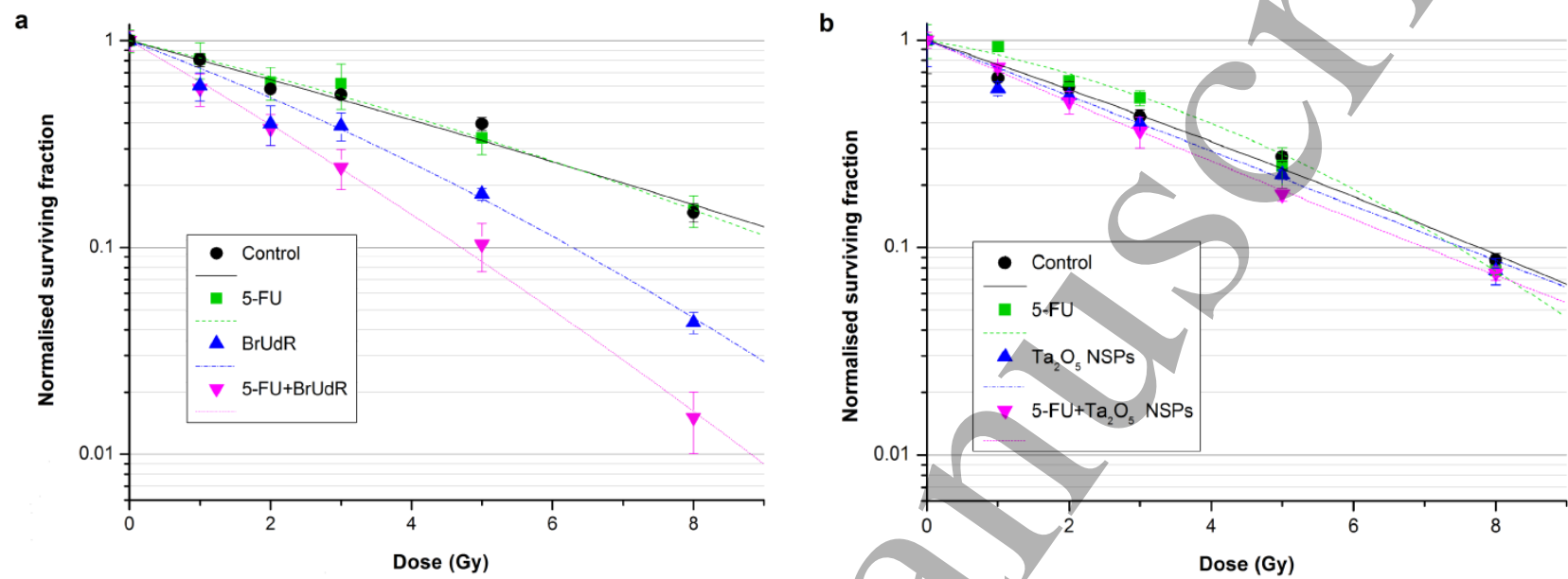

Figure 6. Dose effect relationship of $9 \mathrm{~L}$ cells irradiated with orthovoltage $\mathrm{x}$-rays and pre-exposed with (a) 5$\mathrm{FU}+\mathrm{BrUdR}$ irradiated with $125 \mathrm{kVp}$ x-ray and (b) 5-FU + $\mathrm{Ta}_{2} \mathrm{O}_{5}$ NSPs irradiated with $150 \mathrm{kVp}$ x-ray with and without the individual components of the combination, of 3 independent experiments. Errors bars represent the SEM.

Table 1. Radiation sensitivity parameters for $125 \mathrm{kVp}$ irradiated gliosarcoma cancer cell line treated with 5-FU + BrUdR with and without the individual components of the combination.

\begin{tabular}{cccc} 
& & & \\
\hline & $\alpha\left(\mathrm{Gy}^{-1}\right)$ & $\beta\left(\mathrm{Gy}^{-2}\right)$ & $\mathrm{SER}_{10 \%}$ \\
\hline Control & & & \\
5-FU $(0.01 \mu \mathrm{M})$ & $0.21 \pm 0.03$ & $0.002 \pm 0.006$ & N/A \\
BrUdR $(10 \mu \mathrm{M})$ & $0.29 \pm 0.04$ & $0.011 \pm 0.006$ & 1.58 \\
5 -FU $(0.01 \mu \mathrm{M})+\mathrm{BrUdR}(10 \mu \mathrm{M})$ & $0.47 \pm 0.03$ & $0.007 \pm 0.005$ & 2.11 \\
\hline \hline
\end{tabular}

$\alpha$ and $\beta$ are radiosensitivity parameters. Values are presented as mean \pm SD.

$\mathrm{SER}_{10 \%}=$ sensitisation enhancement ratio at $10 \%$ surviving fraction. 
Table 2. Radiation sensitivity parameters for $150 \mathrm{kVp}$ irradiated gliosarcoma cancer cell line treated with $5-\mathrm{FU}+\mathrm{Ta}_{2} \mathrm{O}_{5} \mathrm{NSPs}$ with and without the individual components of the combination.

\begin{tabular}{cccc}
\hline \hline & $\alpha\left(\mathrm{Gy}^{-1}\right)$ & $\beta\left(\mathrm{Gy}^{-2}\right)$ & $\mathrm{SER}_{10 \%}$ \\
Control & $0.27 \pm 0.04$ & $0.004 \pm 0.007$ & N/A \\
5 -FU $(0.01 \mu \mathrm{M})$ & $0.14 \pm 0.03$ & $0.022 \pm 0.004$ & 1.03 \\
$\mathrm{Ta}_{2} \mathrm{O}_{5} \mathrm{NSPs}(113 \mu \mathrm{M})$ & $0.31 \pm 0.01$ & $\mathrm{~N} / \mathrm{A}$ & $\mathrm{N} / \mathrm{A}$ \\
5-FU $(0.01 \mu \mathrm{M})+\mathrm{Ta}_{2} \mathrm{O}_{5} \mathrm{NSPs}$ & $0.35 \pm 0.02$ & 1.1 \\
$(113 \mu \mathrm{M})$ & & \\
\hline \hline$\alpha$ and $\beta$ are radiosensitivity parameters. Values are presented as mean $\pm \mathrm{SD}$. & \\
$\mathrm{SER}_{10 \%}=$ sensitisation enhancement ratio at 10\% surviving fraction.
\end{tabular}

The irradiated 9L cells pre-exposed to $0.01 \mu \mathrm{M}$ 5-FU with and without $10 \mu \mathrm{M}$ BrUdR or $113 \mu \mathrm{M}$ of $\mathrm{Ta}_{2} \mathrm{O}_{5}$ NSPs resulted in the survival curves presented in Figure 6. The 5-FU demonstrated no enhanced sensitisation effect of the $\mathrm{x}$-ray irradiation on the clonogenic survival of $9 \mathrm{~L}$ cells in both $150 \mathrm{kVp}$ and in the $125 \mathrm{kVp}$. BrUdR-incorporated cells significantly enhanced the biological effect of the X-ray irradiation compared with the $\mathrm{Ta}_{2} \mathrm{O}_{5}$ NSPs-incorporated cells (Figure 6). The SF were substantially decreased with the cells treated with 5-FU+BrUdR compared to the sensitise effect of their individual components. This significant degree of radiation dose enhancement bestowed a synergistic effect as a result. The increase in the $\alpha$ and $\beta$ parameters in the linear quadratic curves can be drawn from the Figure 6a and are displayed in Table 1. Conversely, similar effects were not observed with $\mathrm{Ta}_{2} \mathrm{O}_{5} \mathrm{NSPs}$ treated cells irradiated at the $150 \mathrm{kVp}$. The survival curve of $\mathrm{Ta}_{2} \mathrm{O}_{5}$ NSPs displayed no radiosensitising enhancement from the control curve with $150 \mathrm{kVp} \mathrm{x}$-ray. In particular, the $\mathrm{Ta}_{2} \mathrm{O}_{5}$ NSPs were irradiated in the optimum energy spectrum, however this seems to be ineffective in increasing radiosensitisation. Nevertheless, the combination of 5-FU and $\mathrm{Ta}_{2} \mathrm{O}_{5} \mathrm{NSPs}$ exhibited radiation enhancement which can be seen from Figure $6 \mathrm{~b}$ and the increase in $\alpha$ and decrease in $\beta$ components of the linear quadratic curves is evident on Table 2.

\section{Comparison of 5-FU + BrUdR with 5-FU + $\mathrm{Ta}_{2} \mathrm{O}_{5} \mathrm{NSPS}$ with $\mathrm{MV} x$-ray}
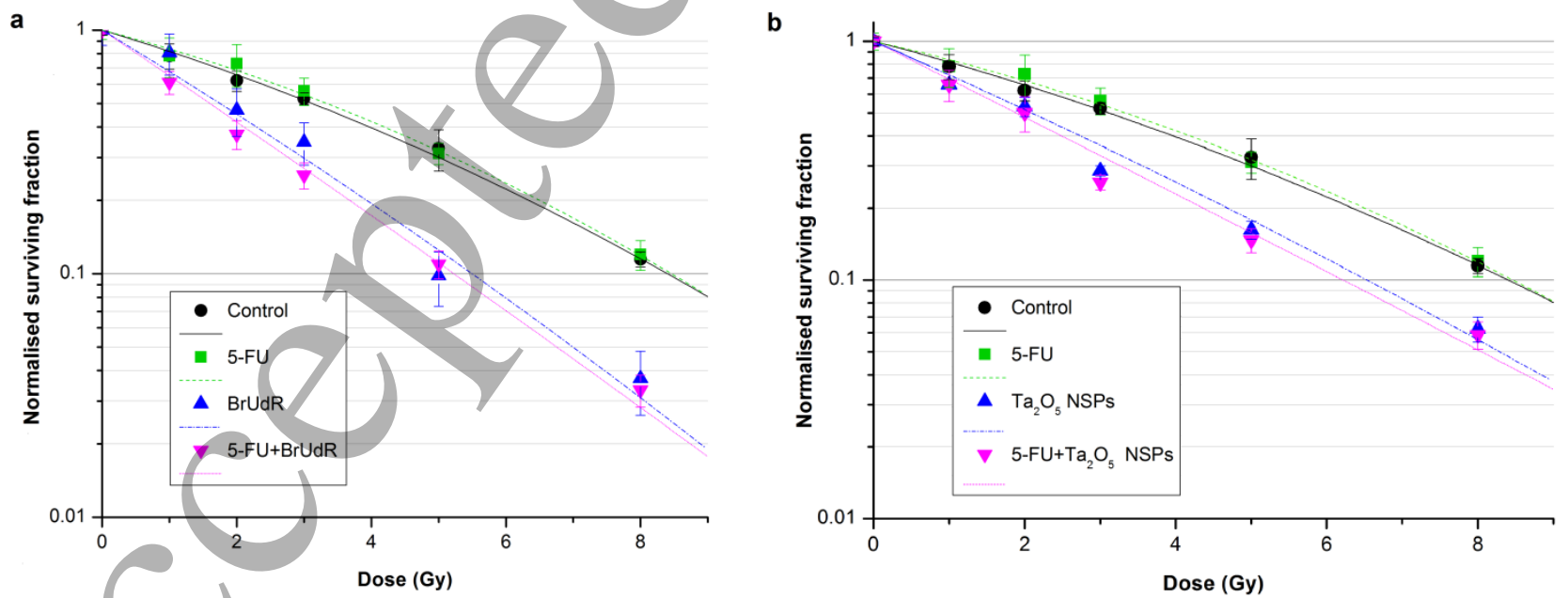

Figure 7. Dose effect relationship of 9L cells irradiated with 10MV x-rays and pre-exposed with (a) 5-FU + BrUdR and (b) 5-FU $+\mathrm{Ta}_{2} \mathrm{O}_{5} \mathrm{NSPs}$ with and without the individual components of the combination, of 3 independent experiments. Errors bars represent the SEM. 
8

Table 3. Radiation sensitivity parameters for $10 \mathrm{MV}$ irradiated gliosarcoma cancer cell line treated with 5-FU + BrUdR with and without the individual components of the combinations.

\begin{tabular}{cccc}
\hline \hline & $\alpha\left(\mathrm{Gy}^{-1}\right)$ & $\beta\left(\mathrm{Gy}^{-2}\right)$ & $\mathrm{SER}_{10 \%}$ \\
\hline Control & & & \\
$5-\mathrm{FU}(0.01 \mu \mathrm{M})$ & $0.19 \pm 0.01$ & $0.010 \pm 0.002$ & $\mathrm{~N} / \mathrm{A}$ \\
$\mathrm{BrUdR}(10 \mu \mathrm{M})$ & $0.17 \pm 0.01$ & $0.013 \pm 0.002$ & 1.53 \\
5-FU $(0.01 \mu \mathrm{M})+\mathrm{BrUdR}(10 \mu \mathrm{M})$ & $0.43 \pm 0.02$ & $\mathrm{~N} / \mathrm{A}$ & 1.61 \\
\hline \hline and $\beta_{\text {are radiosensitivity parameters. Values are presented as mean } \pm \text { SD. }}$ & \\
SER $_{10 \%}=$ sensitisation enhancement ratio at 10\% surviving fraction.
\end{tabular}

Table 4. Radiation sensitivity parameters for $10 \mathrm{MV}$ irradiated gliosarcoma cancer cell line treated with $5-\mathrm{FU}+\mathrm{Ta}_{2} \mathrm{O}_{5}$ NSPs with and without the individual components of the combinations.

\begin{tabular}{cccc}
\hline \hline & $\alpha\left(\mathrm{Gy}^{-1}\right)$ & $\beta\left(\mathrm{Gy}^{-2}\right)$ & $\mathrm{SER}_{10 \%}$ \\
\hline Control & & & \\
5-FU $(0.01 \mu \mathrm{M})$ & $0.19 \pm 0.01$ & $0.010 \pm 0.002$ & N/A \\
$\mathrm{Ta}_{2} \mathrm{O}_{5} \mathrm{NSPs}(113 \mu \mathrm{M})$ & $0.17 \pm 0.01$ & $0.013 \pm 0.002$ & 1 \\
5 -FU $(0.01 \mu \mathrm{M})+\mathrm{Ta}_{2} \mathrm{O}_{5} \mathrm{NSPs}$ & $0.32 \pm 0.01$ & $0.005 \pm 0.002$ & 1.29 \\
$(113 \mu \mathrm{M})$ & $0.37 \pm 0.01$ & N/A & 1.35 \\
\hline \hline
\end{tabular}

$\alpha$ and $\beta$ are radiosensitivity parameters. Values are presented as mean \pm SD.

$\mathrm{SER}_{10 \%}=$ sensitisation enhancement ratio at $10 \%$ surviving fraction.

In view of the clinical importance of MV radiation therapy, comparisons of the two combinations (5FU+BrUdR and 5-FU+Ta2O5 NSPs) were also assessed using 10MV. Similar to that observed in kilovoltage radiation, 5-FU demonstrated no effect in sensitising cells as shown in the Figure 7. The radiosensitisation enhancement in the survival curve of the $\mathrm{BrUdR}$ and $\mathrm{Ta}_{2} \mathrm{O}_{5}$ NSPs were observed in this higher irradiated energy. The results for the $9 \mathrm{~L}$ cells treated with the combination (i.e. 5-FU+BrUdR or 5-FU+ $\mathrm{Ta}_{2} \mathrm{O}_{5} \mathrm{NSPs}$ ) administered concomitantly with $10 \mathrm{MV}$ irradiation showed a cell kill greater than what achieved by its individual components alone. Figure 7 clearly illustrated that neither the combination attained statistically significant greater effects than their respectively high- $Z$ standalone results. However, their survival curves displayed absolutely no shoulder, suggesting some increase in complex lethal damage from secondary electrons due to the inhibiting of the cellular repair, instigated by the 5-FU. In addition, significant increases of $\alpha$ value were obtained and the quadratic parameter $\beta$ decreased to none for both combinations (see Table 3 and 4). This increase in $\alpha$ and decrease in $\beta$ indicates a more effective cell kill which is significant from the clinical view point. 


\section{DISCUSSION}

Concurrent chemoradiotherapy is an effective component of modern cancer therapy, but it is still ultimately limited by the fact that some cancer cells such as $9 \mathrm{~L}$ cells are resistant to ionising radiation and chemotherapy. Hence, there is a need to introduced high- $Z$ elements into the tumour to increase the probability of ionisation events leading to enhanced deposition of energy to destroy tumour cells.

\section{$\mathrm{BrUdR}$ and $\mathrm{Ta}_{2} \mathrm{O}_{5} \mathrm{NSPs}$ subcellular localisation demonstrates fundamental differences}

BrUdR is a halogenated pyrimidine that has a similar chemical structure with the natural pyrimidines and thus can be incorporated into the DNA chains during the DNA synthesising phase. BrUdR is therefore a provider of high Z-radiosensitiser atoms (i.e. bromine) which are incorporated into DNA. $32 \%$ of the DNA was found to be substituted by BrUdR, halogenated thymidine analogues. This finding is fundamental as the degree to which the cells are sensitised to the radiation is dependent on the amount of the halogenated pyrimidine being incorporated into the DNA. In accordance with our findings, a study conducted by Aoyama et al (1964) also found the BrUdR to be 33\% using a similar BrUdR concentration. The remaining amount of Bromide is distributed in the cell nucleus, cytoplasm, and outside the cells.

In the case of $\mathrm{Ta}_{2} \mathrm{O}_{5}$ NSPs, due to its larger size, it is only able to infiltrate into the cytoplasm. The results of this study indicate an increase of forty-five percent in the cellular granularity. This suggested an uptake of NSPs in the treated cells in comparison to the untreated cells. Additionally, the confocal image showed that the majority of the NSPs were either internalised or in close proximity to the cell cytoplasm.

Taken together, the incorporation of $32 \%$ Bromide into the DNA appeared to be the main catalyst for the results observed, and is due to the double strand breaks (DSB) in the DNA when combined with radiation in $\mathrm{kVp}$. This appeared to also be true for the other Bromide that was inaccessible to the DNA when in the presence of radiation using MV. In comparison, $\mathrm{Ta}_{2} \mathrm{O}_{5}$ NSPs was observed to exhibit radiation enhancement only when using MV. This is because $\mathrm{Ta}_{2} \mathrm{O}_{5}$ NSPs is found situated outside the cell nucleus. Additionally, $\mathrm{Ta}_{2} \mathrm{O}_{5}$ NSPs form agglomerates that may absorb secondary electrons (Brown et al 2014).

\section{Minimal cytotoxicity effect of the $\mathrm{BrUdR}+5-\mathrm{FU}$ and $\mathrm{Ta}_{2} \mathrm{O}_{5} \mathrm{NSPS}+5-\mathrm{FU}$ on the cells is maintained in} order to maximise the use of $x$-ray radiation in targeting the cancerous cells

The surviving fraction of each individual agent is relatively high (see Figure 5). It is important that high cell surviving fraction is maintained in the combination (i.e. $\mathrm{BrUdR}+5 \mathrm{FU}$ and $\mathrm{Ta}_{2} \mathrm{O}_{5} \mathrm{NSPs}+5$-FU) to minimise unirradiated cell toxicity. In the clinical treatment, these cells may be healthy cells that are surrounding the tumour target. For this reason, the primary killing mechanism needs to originate from the $\mathrm{x}$-ray radiation.

\section{Radiation sensitization enhancements strongly depends on radiation energy and high $Z$ localisation}

The interaction of BrUdR with x-rays results in the emission of Auger electrons, photoelectrons, Compton scattering electrons, and electron-positron pair production. These electrons range from the nanometer-scale to several micrometers. Whilst the interaction of BrUdR-treated cells with $\mathrm{x}$-rays has a higher interaction cross section at lower radiation energy $(\mathrm{kV})$, using higher energy (10 MV) photons has demonstrated to be

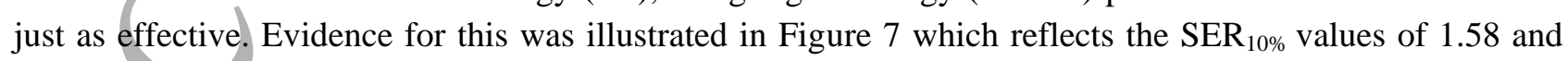
1.53 respectively. The result obtained in this experiment for the radiosensitisation effect of BrUdR using the $\mathrm{kV}$ energies is incongruent with that of Aoyama et al (1964). 
An increase in the $\alpha$ component and the $\alpha / \beta$ ratio in the LQM suggests a greater early response for the BrUdR exposed 9L cells to the MV irradiation, when fit to the SF data at MV compared to $\mathrm{kVp}$. The increase in $\alpha / \beta$ ratio was also contributed by the decrease in the quadratic $\beta$ parameter. This positive result for BrUdR in the MV irradiated energies could inform the future the clinical potential of BrUdR.

The increase in $\alpha$ and decrease in the $\beta$ achieved for $\mathrm{BrUdR}$ in the $10 \mathrm{MV}$ is most likely due to the interaction between the BrUdR compound surrounding the cell nucleus and the Compton scattering electron. Compton scattering electron is the dominant interactive mechanism for MV photons in water. This interaction may have resulted in significant number of secondary electrons being formed within a cell. Additionally, the back scattered photons ( 120 keV median energy) was expected to interact with the BrUdR compound, contributing to a greater number of secondary electrons being created. Together, forming of these secondary electrons meant a more densely ionisation tracks at the DNA site. This aids the cells in becoming more responsive and susceptible to radiation, which in turn enhanced the effectiveness of the treatment.

The radiation enhancement effect of BrUdR has been shown to be independent of the photon energy as opposed to $\mathrm{Ta}_{2} \mathrm{O}_{5}$ NSPs that displayed a radio-enhancing effect only in the MV energy beam (i.e., $\mathrm{SER}_{10 \%}$ of 1.29). The radio enhancing effect of $\mathrm{Ta}_{2} \mathrm{O}_{5}$ NSPs found in this study was comparable to a previous research that reported a $\mathrm{SER}_{10 \%}$ of 1.33 for the thermal decomposition synthesísing $\mathrm{Ta}_{2} \mathrm{O}_{5}$ NSPs material (Brown et al 2014).

High Z NSPs in close proximity to the cell when interacting with the beam can trigger the photoelectric or Compton effects that can cause damage to the surrounding cancerous cells. However, this result did not account for the absence of the dose enhancement effects of $\mathrm{Ta}_{2} \mathrm{O}_{5}$ NSPs at its optimum radiated energy of $150 \mathrm{kVp}$ (i.e., $\mathrm{SER}_{10 \%}$ of 1.03). Previous research has shown radiosensitisation effects of the NSPs to be stronger for low-energy beams (Jain et al 2011). With the $\mathrm{Z}$ of $\mathrm{Ta}_{2} \mathrm{O}_{5}$ NSPs as high as 73 , a promising dose enhancement is expected for majority of the high- $Z$ elements present in the cells (Kobayashi et al 2010). Doubling the $\mathrm{Z}$ value of the $\mathrm{BrUdR}$ compound $(\mathrm{Z}=35)$ and also higher concentration applied, a high $\mathrm{SER}_{10 \%}$ in $\mathrm{kV}$ was also anticipated for $\mathrm{Ta}_{2} \mathrm{O}_{5}$ NSPs despite the compound being only in close proximity to the cell nucleus. However, the finding from this study (see Figure 6) did not demonstrate this.

Nanoparticles related radiation dose enhancement is predominantly dependent on a number of factors such as the size of the nanoparticles, the concentration of nanoparticles applied, surface properties of nanoparticles and the radiation energy ( $\mathrm{Xu}$ et al 2009). The surface chemical reactivity of $\mathrm{Ta}_{2} \mathrm{O}_{5} \mathrm{NSPs}$ is neutral and thus induces very low toxicity (Brown et al 2017). Additionally, the surface properties are mainly concerned with the approach of binding to the cancerous cells in the theranostic system and this is out of our scope in these studies. The crystallite size of the $\mathrm{Ta}_{2} \mathrm{O}_{5}$ NSPs utilised in this research have a mean size of 50-100nm and was irradiated with its optimum $150 \mathrm{kVp}$ X-rays. This corresponds with a previous research that reported $50 \mathrm{~nm}$ size gold NSPs to achieve the best radiosensitising effect (Chithrani et al 2010). However, other studies have reported mixed findings in relation to the optimal size of NSPs (Kong et al 2008, Rahman et al 2009, Hainfeld et al 2008). Despite sonicating the $\mathrm{Ta}_{2} \mathrm{O}_{5}$ NSPs prior to adding into the cells, the result obtained in this research following the internalisation of NSPs in the cells after 24 hours was marginally small. An explanation for this is observed in the confocal images that shows formation of agglomerate of $\mathrm{Ta}_{2} \mathrm{O}_{5}$ NSPs. Hence, the bulk size of the $\mathrm{Ta}_{2} \mathrm{O}_{5}$ NSPs absorbed the majority of the low-energy short range electrons produced by the $\mathrm{kV}$ radiation. This subsequently hinders the $\mathrm{Ta}_{2} \mathrm{O}_{5} \mathrm{NSPs}$ from depositing their energy on the target cancerous cells (Brown et al 2014 and 2017, McKinnon et al 2016). The result obtained in this study is significant because it does not follow the conventional finding of other high $\mathrm{Z}$ nanoparticles studies, where radiation dose enhancement is dominant in the $\mathrm{kV}$ radiated energy (Algethami et al 2015, Rahman et al 2009, Luchette et al 2014). This is due to the photoelectric effect which is prevailing until the 
photon energy reaches $500 \mathrm{keV}$ (Retif et al 2015). Firstly, to achieve a dose enhancement in megavoltage for $\mathrm{Ta}_{2} \mathrm{O}_{5}$ NSPs has more clinical potential than in the kilovoltage region as it could target most of the tumours localisation. Additionally, to also achieve a negligible dose enhancement in $\mathrm{kV}$ for $\mathrm{Ta}_{2} \mathrm{O}_{5} \mathrm{NSPs}$, provide insight for our near future in vivo model to utilise On-Board-kilovoltage imaging system (operating range at $40-150 \mathrm{kVp}$ using a dose $\sim 2 \mathrm{cGy}$ ) as a part of the image-guided radiotherapy linear accelerator. The absence of dose enhancement in the kilovoltage region would not increase energy deposit due to an On-Boardkilovoltage imager which is an advantage in the sense that this dose enhancement would be very difficult to take into account precisely as current treatment planning systems do not model kilovoltage imaging doses accurately.

a

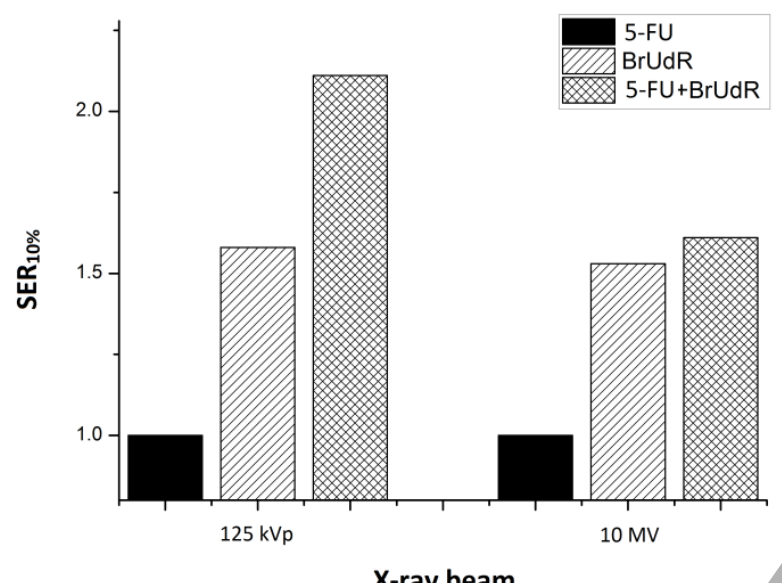

b

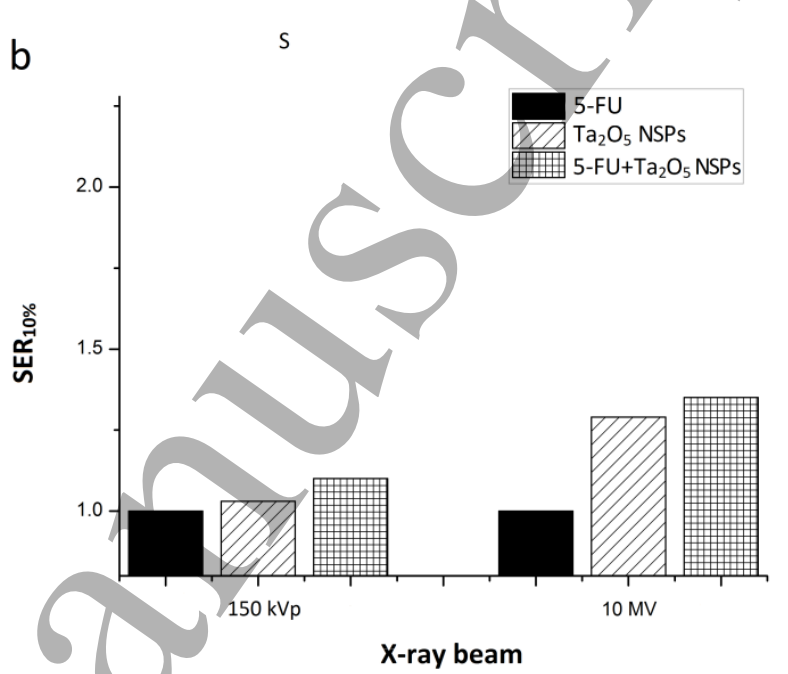

Figure 8. Comparison of the sensitisation enhancement ratio $\left(\mathrm{SER}_{10 \%}\right)$ for cells pre-treated with (a) 5$\mathrm{FU}+\mathrm{BrUdR}$ and (b) 5-FU+Ta $\mathrm{O}_{5}$ NSPs with and without the individual components of the combination in their respective optimum 125 and 150 kilovoltage and 10 megavolt photons energy.

\section{Radiation sensitization enhancements of 5-FU strongly depends on how drastic the damage on the DNA target induced by the high $\mathrm{Z}$}

To date, the combination of 5-FU with radiation has been extensively used and is the most promising clinical radiosensitiser (McGinne and Lawrence 2001). In this research, the dose enhancement was not observed in the 5-FU survival curve, for all radiation energies used. One possible explanation could be that the concentration of 5-FU used in our studies is 100 times lower than that of the half maximal concentration to inhibit the biological process (IC50). The 5-FU has shown to enhance the radiation sensitisation of both BrUdR and $\mathrm{Ta}_{2} \mathrm{O}_{5}$ NSPs in both $\mathrm{kVp}$ and MV energies (see Figure $6 \&$ 7). Particularly, the synergistic effect was achieved with the 5-FU+BrUdR in the $\mathrm{kVp}$. The measured values of $\mathrm{SER}_{10 \%}$ for 5-FU+BrUdR and 5$\mathrm{FU}+\mathrm{Ta}_{2} \mathrm{O}_{5}$ NSPs in the $\mathrm{kVp}$ (see Tables 1 and 2, and Figure 8) were significantly different with an incomparable result of 2.11 and 1.10 respectively. This significant difference is hypothesised to be due to BrUdR creating a more drastic and complex damage to DNA than $\mathrm{Ta}_{2} \mathrm{O}_{5} \mathrm{NSPs}$ in the $\mathrm{kVp}$. Thus, require a greater repair process, which can be achieved through lowering the concentration of 5-FU.

At $10 \mathrm{MV}$, the $\mathrm{SER}_{10 \%}$ for both combinations of 5-FU+BrUdR and 5-FU+ $\mathrm{Ta}_{2} \mathrm{O}_{5} \mathrm{NSP}$ is measured to be 1.61 and 1.35 respectively (see Figure 8). No significant difference in the degree of enhancement was found between $\mathrm{BrUdR}$ and 5-FU+BrUdR, and $\mathrm{Ta}_{2} \mathrm{O}_{5}$ NSPs and 5-FU+ $\mathrm{Ta}_{2} \mathrm{O}_{5}$ NSPs. That is, both combinations yielded the same percentage increase by $5 \%$ in $\mathrm{SER}_{10 \%}$. The degree of enhancement was nonsignificant. We 60 
damages being from the lower LET secondary electrons. Consequently, the concentration of 5-FU utilised in this study blocked the repair of radiation injury quite effectively. Nevertheless, 5-FU did display a visible sensitising effect in both combination in both $\mathrm{kV}$ and MV energies. This is evident in the increase in the $\alpha$ and decrease in $\beta$ component of the survival curves (see Table 1, 2, \& 3). The reason being was that no shoulder was observed in the survival curves for both combinations, in MV and kV (see Figures 6 and 7). The shoulder denotes the capacity of cells to repair itself after being damage by radiation, which is a general characteristic of the cell survival curve after irradiation. In support of this, a study has found the 5-FU drug to independently decrease the width of the survival curve shoulder as the concentration of the drugs increased in two human cells lines (Kim et al 1993).

In this study, the 5-FU drug alone was not found to radiosensitise the cell. As such, the increased sub-lethal damage achieved in both the $5-\mathrm{FU}+\mathrm{BrUdR}$ and the $5 \mathrm{FU}+\mathrm{Ta}_{2} \mathrm{O}_{5}$ combinations was due to high- $\mathrm{Z}$ triggering the mechanism of 5-FU to inhibit cell repair. The sensitisation mechanism of 5-FU is not fully understood in the past however different studies including Kim et al (1993) and Nakajima et al (1979) proposed that 5-FU acted as an inhibitor of cells repair from radiation damage rather than direct enhancement of sub-lethal damage during exposure to radiation. Our results proven their hypothesis to be true as well as agreed with what we proposed to happen with the combination of 5-FU with a high-Z in the $10 \mathrm{MV}$ irradiated energy.

In spite of the aforementioned findings, this study found the sensitisation mechanism of the 5-FU drug is sufficient only in producing a synergistic effect for the $5-\mathrm{FU}+\mathrm{BrUdR}$ in the $125 \mathrm{kVp}$ (see Figure 6). Previous research has shown that for 5-FU to sensitise cells to radiation, a degree of 5-FU toxicity needs to be achieved (Byfield et al 1982). Translating this to our study means that a higher concentration of 5-FU may be needed in order to observe radiosensitisation at our irradiated energies and by extension, an accountable $\mathrm{SER}_{10 \%}$ in its combination with the high-Z. Another research has also demonstrated the 5-FU drug to efficiently sensitised another radioresistant cancer cell line with $6 \mathrm{MV}$ x-ray at a concentration of $100 \mu \mathrm{M}$ (Hajikarimi et al 2004). This concentration is 10000 times higher at a lower irradiated MV energy than what is used in this study. Similarly, another research also reported a concentration of 5-FU of $\geq 0.1 \mu \mathrm{M}$ to be the critical combination in radiosensitising a radioresistance colon cancer cell lines (Ojima et al 2006). Hence, in order to achieve a good synergistic/additive effect between 5-FU and a high- $\mathrm{Z}$ in the MV irradiated energies, a concentration of 5-FU up to at least 100 times higher may need to be trialled. However, the use of this critical concentration or higher would result in a significant increase in cytotoxicity of cells including the healthy cells. Alternatively, increasing the concentration of the high $\mathrm{Z}$ material in order to create a high LET electron environment can potentially bestow the synergistic effects in this clinically relevant X-ray energy field. Future research could possibly examine ways to enhance the effect of cell death in the MV energy range given that a high-energy beam is currently a more favoured clinical application in the treatment of deep tumours (>2 cm in depth) compared to conventional kilovoltage beams. Alternatively, kilovoltage Synchrotron radiation beams, geometrically spaced in Microbeams, would possess the required physical properties to allow for adequate energy deposition at the tumour combined with exceptional normal tissue sparing capabilities. Translation of this multimodal treatment to a pre-clinical in vivo model like the well accepted experimental neuro-oncological model, Fisher 344 rats with $9 \mathrm{~L}$ brain gliosarcoma, would be an essential step toward potential future clinical application, allowing for the intrinsic complexity of physiological factors of tumour and normal tissues responses to be fully apprehended.

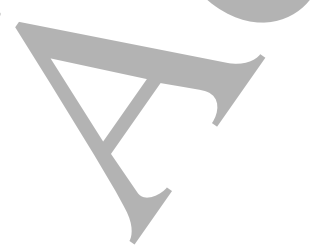




\section{CONCLUSION}

556

557

7558

8559

9560

${ }_{11}^{10} 561$

12562

13563

14564

15565

17566

18567

19568

20569

21570

23571

24572

25573

26574

27575

29576

30577

31578

32579

34580

35581

36582

37583

38584

39585

40586

41586

42587

43588

44589

45590

46590

47591

48592

49593

50594

51595

52596

53597

54598

55599

56600

57601

58602

59603

60

In this paper, we have experimentally demonstrated the radiosensitisation enhancement effect of BrUdR and $\mathrm{Ta}_{2} \mathrm{O}_{5}$ NSPs, with respect to their $\mathrm{Z}$ and location from the cell nucleus. BrUdR has shown to radiosensitise in both the $\mathrm{kVp}$ and MV x-ray beams. The $\mathrm{kVp}$ beam interacted with the localised BrUdR, which generated high LET secondary electrons that created clustered damage on the DNA. The dose enhancement achieved with the MV beam is hypothesised to be from the non-localised BrUdR. The MV beam interacted with the BrUdR located in proximity of the DNA, generated low LET but higher kinetic energy secondary electrons that reached the DNA target to cause sub-lethal damage. $\mathrm{Ta}_{2} \mathrm{O}_{5}$ NSPs radiosensitised the $9 \mathrm{~L}$ cancer cells selectively in the $10 \mathrm{MV}$ irradiation field. The radiation dose enhancement achieved was from the same type of secondary electrons generated by the non-localised BrUdR in the MV beam. The formation of $\mathrm{Ta}_{2} \mathrm{O}_{5}$ NSPs around the cells absorbed the high LET secondary electrons generated in the $\mathrm{kVp}$ beam, scavenged radiation dose that was to be deposited on the DNA target. These results highlight the importance of high $\mathrm{Z}$ material to be small on the scale that they can be subcellular localised to give radiation dose enhancement in the $\mathrm{kV}$ radiation fields. The dominating factor to dose enhancement for high $\mathrm{Z}$ material shifted towards achieving their distribution within the whole target volume in order to maximise the radiation dose enhancement in the clinically relevant radiation energy of $10 \mathrm{MV}$.

A relevant synergistic effect is achieved only with $5-\mathrm{FU}+\mathrm{BrUdR}$ in the $\mathrm{kVp}$ radiation. This is due to more drastic and complex damages induced by BrUdR under the exposure of radiation. This type of damages achieved by the high LET secondary electron demand a greater repair process. At the $10 \mathrm{MV}$, the $\mathrm{SER}_{10 \%}$ obtained for 5-FU+BrUdR and 5-FU+ $\mathrm{Ta}_{2} \mathrm{O}_{5} \mathrm{NSPs}$ is only a marginal increase from their respective high $\mathrm{Z}$ standalone results. The damage induced by the high $\mathrm{Z}$ is less substantial in the MV beam. This is due to the damage being from the lower LET secondary electron generation. These findings prove that the effect of 5FU is dependent on how severe the damage is on the DNA target. These in turn are dependent on the LET, size and localisation of high $\mathrm{Z}$ molecule/particle and kinetic energy of secondary electron.

\section{ACKNOWLEDGMENTS}

The authors wish to thank the technical staff at the Illawarra Health and Medical Institute for their diligence in maintaining the facilities required to conduct the experiments needed for this work. The authors would also like to acknowledge the financial support from the National Health and Medical Research Council (APP1084994).

\section{REFERENCES}

Adelstein, D.J., Li, Y., Adams, G.L., Wagner Jr, H., Kish, J.A., Ensley, J.F., Schuller, D.E. and Forastiere, A.A., 2003. An intergroup phase HI comparison of standard radiation therapy and two schedules of concurrent chemoradiotherapy in patients with unresectable squamous cell head and neck cancer. Journal of clinical oncology, 21(1), pp.92-98.

Algethami, M., Geso, M., Piva, T., Blencowe, A., Lu, L., Ai, K., Harty, P. and Gan, E., 2015. Radiation dose enhancement using Bi2S3 nanoparticles in cultured mouse PC3 prostate and B16 melanoma cells. NanoWorld Journal, 1(3), pp.97-102.

Antosh, M.P. et al., 2015. Enhancement of radiation effect on cancer cells by gold-pHLIP. Proceedings of the National Academy of Sciences, 112(17), pp.5372-5376. 
Aoyama, T., Kondo, T., Horikawa, M. and Sugahara, T., 1964. Effect of halogenated pyrimidines on radiosensitivity of mouse strain L cells and their radioresistant variant. Journal of radiation research, 5(1), pp.39-48.

Baglan, K.L., Frazier, R.C., Yan, D., Huang, R.R., Martinez, A.A. and Robertson, J.M., 2002. The dose-volume realationship of acute small bowel toxicity from concurrent 5-FU-based chemotherapy and radiation therapy for rectal cancer. International Journal of Radiation Oncology* Biology* Physics, 52(1), pp.176-183.

Bedenne, L. et al., 2007. Chemoradiation followed by surgery compared with chemoradiation alone in squamous cancer of the esophagus: FFCD 9102. Journal of Clinical Oncology, 25(10), pp.1160-1168.

Brown, R., Tehei, M., Oktaria, S., Briggs, A., Stewart, C., Konstantinov, K., Rosenfeld, A., Corde, S. and Lerch, M., 2014. High-Z Nanostructured Ceramics in Radiotherapy: First Evidence of Ta2O5-Induced Dose Enhancement on Radioresistant Cancer Cells in an MV Photon Field. Particle \& Particle Systems Characterization, 31(4), pp.500-505.

Brown, R., Corde, S., Oktaria, S., Konstantinov, K., Rosenfeld, A., Lerch, M. and Tehei, M., 2017. Nanostructures, concentrations and energies: an ideal equation to extend therapeutic efficiency on radioresistant 9L tumor cells using ceramic nanostructured particles. Biomedical Physics \& Engineering Express, 3(1), pp.015018.

Buzea, C., Pacheco, I.I. and Robbie, K., 2007. Nanomaterials and nanoparticles: Sources and toxicity. Biointerphases, 2(4), pp.MR17-MR71.

Byfield, J.E., Calabro-Jones, P., Klisak, I. and Kulhanian, F., 1982. Pharmacologic requirements for obtaining sensitization of human tumor cells in vitro to combined 5-fluorouracil or ftorafur and X rays. International Journal of Radiation Oncology* Biology* Physics, 8(11), pp.1923-1933.

Chithrani, D.B., Jelveh, S., Jalali, F., van Prooijen, M., Allen, C., Bristow, R.G., Hill, R.P. and Jaffray, D.A., 2010. Gold nanoparticles as radiation sensitizers in cancer therapy. Radiation research, 173(6), pp.719-728.

Corde, S., Joubert, A., Adam, J.F., Charvet, A.M., Le Bas, J.F., Esteve, F., Elleaume, H. and Balosso, J., 2004. Synchrotron radiation-based experimental determination of the optimal energy for cell radiotoxicity enhancement following photoelectric effect on stable iodinated compounds. British journal of cancer, 91(3), pp.544-551.

Damodaran, O., van Heerden, J., Nowak, A.K., Bynevelt, M., Mcdonald, K., Marsh, J. and Lee, G., 2014. Clinical management and survival outcomes of gliosarcomas in the era of multimodality therapy. Journal of Clinical Neuroscience, 21, pp.478-481.

Dewey, W.C. and Humphrey, R.M., 1965. Increase in radiosensitivity to ionizing radiation related to replacement of thymidine in mammalian cells with 5-bromodeoxyuridine. Radiation research, 26(4), pp.538-553.

Doiron, A., Yapp, D.T., Olivares, M., Zhu, J.X. and Lehnert, S., 1999. Tumor radiosensitization by sustained intratumoral release of bromodeoxyuridine. Cancer research, 59(15), pp.3677-3681.

Emens, L.A., Ascierto, P.A., Darcy, P.K., Demaria, S., Eggermont, A.M., Redmond, W.L., Seliger, B. and Marincola, F.M., 2017. Cancer immunotherapy: opportunities and challenges in the rapidly evolving clinical landscape. European Journal of Cancer, 81, pp.116-129.

Epstein, A.H., Cook, J.A., Goffman, T. and Glatstein, E., 1993. Tumour radiosensitization with the halogenated pyrimidines 5'-bromo-and 5'-iododeoxyuridine. British journal of radiology, 66(782, suppl. 24), pp.209-214.

Ghods, A.J., Irvin, D., Liu, G., Yuan, X., Abdulkadir, I.R., Tunici, P., Konda, B., Wachsmann-Hogiu, S., Black, K.L. and Yu, J.S., 2007. Spheres Isolated from 9L Gliosarcoma Rat Cell Line Possess Chemoresistant and Aggressive Cancer Stem-Like Cells. Stem cells, 25(7), pp.1645-1653.

Goldberg, M.S., 2015. Immunoengineering: how nanotechnology can enhance cancer immunotherapy. Cell, 161(2), pp.201-204.

Hainfeld, J.F., Dilmanian, F.A., Slatkin, D.N. and Smilowitz, H.M., 2008. Radiotherapy enhancement with gold nanoparticles. Journal of Pharmacy and Pharmacology, 60(8), pp.977-985.

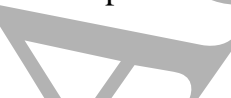


Hajikarimi, Z., Khoei, S., Khoee, S. and Mahdavi, S.R., 2014. Evaluation of the cytotoxic effects of PLGA coated iron oxide nanoparticles as a carrier of 5-fluorouracil and mega-voltage X-ray radiation in DU145 prostate cancer cell line. IEEE transactions on nanobioscience, 13(4), pp.403-408.

5665

6666

7667

8668

9669

10670

11671

12672

13673

14674

15675

16676

17677

17678

18679

19680

20681

21682

22683

23684

24685

25686

26687

27688

28689

29690

30691

31692

32693

33694

34695

35696

36697

37698

38699

39700

40701

41702

41703

42704

43705

44706

45707

46708

47709

48710

49711

50712

51713

52714

53715

54716

55717

56718

57719

58720

59721

60722
Harada, H., Shibuya, K. and Hiraoka, M., 2006. Combinations of Antimetabolites and Ionizing Radiation. Multimodal Concepts for Integration of Cytotoxic Drugs, pp.19-34.

Hoshino, T. and Sano, K., 1969. Radiosensitization of malignant brain tumours with bromouridine (thymidine analogue). Acta radiologica: therapy, physics, biology, 8(1-2), pp.15-26.

Iliakis, G., Kurtzman, S., Pantelias, G. and Okayasu, R., 1989. Mechanism of radiosensitization by halogenated pyrimidines: effect of BrdU on radiation induction of DNA and chromosome damage and its correlation with cell killing. Radiation research, 119(2), pp.286-304.

Iliakis, G., Wang, Y., Pantelias, G.E. and Metzger, L., 1992. Mechanism of radiosensitization by halogenated pyrimidines: effect of BrdU on repair of DNA breaks, interphase chromatin breaks, and potentially lethal damage in plateau-phase CHO cells. Radiation research, 129(2), pp.202-211.

Ilson, D.H., 2008. Esophageal cancer chemotherapy: recent advances. Gastrointestinal cancer research: GCR, 2(2), pp.85.

Jain, S. et al., 2011. Cell-specific radiosensitization by gold nanoparticles at megavoltage radiation energies. International Journal of Radiation Oncology* Biology* Physics, 79(2), pp.531-539.

Kim, W.H., Chon, C.Y., Moon, Y.M., Kang, J.K., Park, I.S. and Choi, H.J., 1993. Effect of anticancer drugs and desferrioxamine in combination with radiation on hepatoma cell lines. Yonsei Med J, 34(1), pp.45-56.

Kobayashi, K., Usami, N., Porcel, E., Lacombe, S. and Le Sech, C., 2010. Enhancement of radiation effect by heavy elements. Mutation Research/Reviews in Mutation Research, 704(1), pp.123-131.

Kong, T., Zeng, J., Wang, X., Yang, X., Yang, J., McQuarrie, S., McEwan, A., Roa, W., Chen, J. and Xing, J.Z., 2008. Enhancement of Radiation Cytotoxicity in Breast-Cancer Cells by Localized Attachment of Gold Nanoparticles. small, 4(9), pp.1537-1543.

Lehnert, S., 2014. Radiosensitizers and Radiochemotherapy in the Treatment of Cancer. CRC Press.

Libutti, S.K., Paciotti, G.F., Byrnes, A.A., Alexander, H.R., Gannon, W.E., Walker, M., Seidel, G.D., Yuldasheva, N. and Tamarkin, L., 2010. Phase I and pharmacokinetic studies of CYT-6091, a novel PEGylated colloidal gold-rhTNF nanomedicine. Clinical cancer research, pp.clincanres-0978.

Longley, D.B., Harkin, D.P. and Johnston,P.G., 2003. 5-fluorouracil: mechanisms of action and clinical strategies. Nature Reviews Cancer, 3(5), pp.330-338.

Luchette, M., Korideck, H., Makrigiorgos, M., Tillement, O. and Berbeco, R., 2014. Radiation dose enhancement of gadolinium-based AGuIX nanoparticles on HeLa cells. Nanomedicine: Nanotechnology, Biology and Medicine, 10(8), pp.1751-1755.

MacDonald, S.M., Ahmad, S., Kachris, S., Vogds, B.J., DeRouen, M., Gittleman, A.E., DeWyngaert, K. and Vlachaki, M.T., 2007. Intensity modulated radiation therapy versus three-dimensional conformal radiation therapy for the treatment of high grade glioma: a dosimetric comparison. Journal of Applied Clinical Medical Physics, 8(2), pp.47-60.

McGinn, C.J. and Lawrence, T.S., 2001, October. Recent advances in the use of radiosensitizing nucleosides. Seminars in Radiation Oncology, 11(4), pp. 270-280.

McKinnon, S., Engels, E., Tehei, M., Konstantinov, K., Corde, S., Oktaria, S., Incerti, S., Lerch, M., Rosenfeld, A. and Guatelli, S., 2016. Study of the effect of ceramic Ta 2 O 5 nanoparticle distribution on cellular dose enhancement in a kilovoltage photon field. Physica Medica, 32(10), pp.1216-1224.

Nakajima, Y., Miyamoto, T., Tanabe, M., Watanabe, I. and Terasima, T., 1979. Enhancement of mammalian cell killing by 5-fluorouracil in combination with x-rays. Cancer research, 39(9), pp.3763-3767. 
Nutting, C.M. et al., 2011. Parotid-sparing intensity modulated versus conventional radiotherapy in head and neck cancer (PARSPORT): a phase 3 multicentre randomised controlled trial. The lancet oncology, 12(2), pp.127-136.

Ojima, E., Inoue, Y., Watanabe, H., Hiro, J., Toiyama, Y., Miki, C. and Kusunoki, M., 2006. The optimal schedule for 5-fluorouracil radiosensitization in colon cancer cell lines. Oncology reports, 16(5), pp.1085.

Oktaria, S., Corde, S., Lerch, M.L., Konstantinov, K., Rosenfeld, A.B. and Tehei, M., 2015. Indirect radio-chemo-beta therapy: a targeted approach to increase biological efficiency of x-rays based on energy. Physics in Medicine and Biology, 60(20), pp.7847.

Oktaria, S., Lerch, M.L., Rosenfeld, A.B., Tehei, M. and Corde, S., 2017. In vitro investigation of the dose-rate effect on the biological effectiveness of megavoltage X-ray radiation doses. Applied Radiations and isotopes, 128, pp.114119.

Ooyama, A., Okayama, Y., Takechi, T., Sugimoto, Y., Oka, T. and Fukushima, M., 2007. Genome-wide screening of loci associated with drug resistance to 5-fluorouracil-based drugs. Cancer science, 98(4), pp.577-583.

Pignol, J.P., Rakovitch, E., Beachey, D. and Le Sech, C., 2003. Clinical significance of atomic inner shell ionization (ISI) and Auger cascade for radiosensitization using IUdR, BUdR, platinum salts, or gadolinium porphyrin compounds. International Journal of Radiation Oncology* Biology* Physics, 55(4), pp.1082-1091.

Poludniowski, G., Landry, G., DeBlois, F., Evans, P.M. and Verhaegen, F., 2009. SpekCalc: a program to calculate photon spectra from tungsten anode x-ray tubes. Physics in Medicine \& Biology, 54(19), pp.N433.

Rahman, W.N., Bishara, N., Ackerly, T., He, C.F., Jackson, P., Wong, C., Davidson, R. and Geso, M., 2009. Enhancement of radiation effects by gold nanoparticles for superficial radiation therapy. Nanomedicine: Nanotechnology, Biology and Medicine, 5(2), pp.136-142.

Restifo, N.P., Smyth, M.J. and Snyder, A., 2016. Acquired resistance to immunotherapy and future challenges. Nature Reviews Cancer, 16(2), p.121.

Retif, P., Pinel, S., Toussaint, M., Frochot, C., Chouikrat, R., Bastogne, T. and Barberi-Heyob, M., 2015. Nanoparticles for radiation therapy enhancement: the key parameters. Theranostics, 5(9), pp.1030.

Saleh, T. and Shojaosadati, S.A., 2016. Multifunctional nanoparticles for cancer immunotherapy. Human vaccines \& immunotherapeutics, 12(7), pp.1863-1875.

Sano, K., Hoshino, T. and Nagai, M., 1968. Radiosensitization of brain tumor cells with a thymidine analogue (bromouridine). Journal of neurosurgery, 28(6), pp.530-538.

Shao, K., Singha, S., Clemente-Casares, X., Tsai, S., Yang, Y. and Santamaria, P., 2014. Nanoparticle-based immunotherapy for cancer. ACS nano, 9(1), pp.16-30.

Spiers, F.W., 1949. The influence of energy absorption and electron range on dosage in irradiated bone. The British journal of radiology, 22(261), pp.521-533.

Van de Water, T.A., Lomax, A.J., Bijl, H.P., de Jong, M.E., Schilstra, C., Hug, E.B. and Langendijk, J.A., 2011. Potential benefits of scanned intensity-modulated proton therapy versus advanced photon therapy with regard to sparing of the salivary glands in oropharyngeal cancer. International Journal of Radiation Oncology* Biology* Physics, 79(4), pp.1216-1224.

Velpurisiva, P., Gad, A., Piel, B., Jadia, R. and Rai, P., 2017. Nanoparticle Design Strategies for Effective Cancer Immunotherapy. Journal of Biomedicine (Sydney, NSW), 2(2), p.64.

Wang, Y., Pantelias, G.E. and Iliakis, G., 1994. Mechanism of radiosensitization by halogenated pyrimidines: the contribution of excess DNA and chromosome damage in BrdU radiosensitization may be minimal in plateau-phase cells. International journal of radiation biology, 66(2), pp.133-142.

Xu, R. et al., 2009. Ag nanoparticles sensitize IR-induced killing of cancer cells. Cell research, 19(8), pp.1031. 